\title{
Corrigendum
}

\section{The Struggle to Diversify Rural Livelihoods: Bio-enterprise Initiatives and their Impacts on Agro-pastoralists and Pastoralists Communities in the Drylands of Kenya}

\author{
Susie Wren and Chinwe Ifejika Speranza \\ European Journal of Development Research (2011) 23, 510. doi:10.1057/ejdr.2010.67
}

Correction to: The European Journal of Development Research (2010) 22, 751-769, doi: $10.1057 /$ ejdr. 2010.42

The authors would like to apologise that the affiliation details for Chinwe Ifejika Speranza and the acknowledgement section were incorrect in the above published paper.

The correct affiliation details for this author are shown below:

Susie Wren ${ }^{\mathrm{a}}$ and Chinwe Ifejika Speranza ${ }^{\mathrm{b}, \mathrm{c}, \mathrm{d}}$

${ }^{a}$ Laikipia Wildlife Forum, Bio-enterprise Development Programme, Nanyuki.

${ }^{\mathrm{b}}$ Centre for Training and Integrated Research for Aid and Semi-arid Lands Development, (CETRAD), Nanyuki, Kenya.

${ }^{\mathrm{c}}$ University of Bern, Bern, Switzerland.

${ }^{\mathrm{d}}$ German Development Institute, Bonn, Germany.

The Acknowledgement section should have appeared as follows:

\section{Acknowledgement}

The Authors wish to thank and fully acknowledge the contribution of information from the International Centre for Insect Physiology and Ecology, Wild Living East Africa, Laikipia Wildlife Forum and other individual sources. Chinwe Ifejika Speranza acknowledges support from the Volkswagen Foundation in the context of the research project "Semi-arid areas in transition", and the Swiss National Centre of Competence in Research (NCCR) North-South: Research Partnerships for Mitigating Syndromes of Global Change, co-funded by the Swiss National Science Foundation (SNSF), the Swiss Agency for Development and Cooperation (SDC), and the participating institutions. 